NBER WORKING PAPER SERIES

\title{
INTERNAL VERSUS EXTERNAL \\ CAPITAL MARKETS
}

Robert H. Gertner

David S. Scharfstein

Jeremy C. Stein

Working Paper No. 4776

\author{
NATIONAL BUREAU OF ECONOMIC RESEARCH \\ 1050 Massachusetts Avenue \\ Cambridge, MA 02138 \\ June 1994
}

We thank Maureen O'Donnell for help in preparing the manuscript. Thanks also to Anne Gron, Oliver Hart, Canice Prendergast, Raghuram Rajan, Andrei Schleifer, Lars Stole. Jean Tirole, Robert Vishny, two referees, and seminar participants at various institutions for helpful comments. This research was supported by the National Science Foundation, the International Financial Services Research Center at the Massachusetts Institute of Technology and a Sloan Foundation Research Fellowship. This paper is part of NBER's research program in Corporate Finance. Any opinions expressed are those of the authors and not those of the National Bureau of Economic Research. 


\title{
INTERNAL VERSUS EXTERNAL CAPITAL MARKETS
}

\begin{abstract}
This paper presents a framework for analyzing the costs and benefits of intemal vs. extemal capital allocation. We focus primarily on comparing an internal capital market to bank lending. While both represent centralized forms of financing, in the former case the financing is owner-provided, while in the latter case it is not. We argue that the ownership aspect of internal capital allocation has three important consequences: 1) it leads to more monitoring than bank lending; 2) it reduces managers' entrepreneurial incentives; and 3) it makes it easier to efficiently redeploy the assets of projects that are performing poorly under existing management.
\end{abstract}

Robert H. Gertner

Graduate School of Business

University of Chicago

1101 East 58th Street

Chicago, IL 60637

Jeremy C. Stein

E52-448, Sloan School of Management Massachusetts Institute of Technology

50 Memorial Drive

Cambridge, MA 02142-1347

and NBER
David S. Scharfstein

E52-433, Sloan School of Management Massachusetts Institute of Technology 50 Memorial Drive Cambridge, MA 02142-1347 and NBER 
$A$ central goal of research in corporate finance is to understand the process by which capital is allocated to the corporate sector. In most work, the focus is on providers of capital that are external to the firm, e.g., the bond market, the stock market, banks and finance companies. Yet, an important part of the capital allocation process takes place in internal markets in which corporate headquarters allocate capital to their business units.

The importance of internal capital markets is underscored by data from the Directory of Corporate Affiliations [1994] which lists 31,419 business units of 3,799 parent companies. Thus, for every company that raises capital from external markets, there are roughly eight internal capital allocation decisions that are made at the business-unit level. Moreover, many of these internal capital market transactions could, in principle, be carried out in external markets. For example, General Electric allocates capital internally to business units as diverse as GE Appliances and GE Plastics, while comparable stand-alone operations such as Maytag (appliances) and A. Schulman (plastics) raise funds directly from the capital market.

What are the costs and benefits of internal versus external financing? An old argument, due to Alchian [1969] and Williamson [1975], contends that a key advantage of an interna] capital market is that it shields investment projects from the information and incentive problems that plague external finance. For example, Alchian writes:

The investment funds (capital) market within General Electric is fiercely competitive and operates with greater speed to clear the market and to make information more avalable to both lenders and borrowers than in the external 'normal' markets. In fact, 1 conjecture that the wealth growth of General Electric derives precisely from the superiority of its internal markets for exchange and reallocation of resources - a superiority arising from the greater (cheaper) information about people alld proposals.

The crux of Alchian's argument is thus that headquarters does a good job of monitoring and information production. However, it is not clear why headquarters is any better in this regard than, say, a bank lender of the sort envisioned in the delegated monitoring modeis of Diamond [1984]. In other words, the benefits tbat Alchian attributes to an internal capital market may simply be benefits of centralized finance, benefits that could be realized in an external market by raising capital from a single (centralized) source. Indeed, in the example above, Maytag and A. Schulman both have a substantial amount of bank debt outstanding. What then are the differences between centralized external finance (e.g., bank debt) and an internal capital market? In our view, an important distinction between the two 
modes of financing is that in an internal market, corporate headquarters owns the business units to which it allocates capital, whereas in an external market, a bank does not own the firms to which it lends. Following Grossman and Hart [1986], we take ownership to mean residual control rights over the use of the firm's assets. Thus, in an internal capital market these control rights reside with the capital supplier (corporate headquarters), while in a bank-lending arrangement they reside with the firm's manager (not the bank). We argue that giving control rights to the capital supplier, as in an internal capital market, has three important consequences:

1) Increased monitoring incentives. Even if internal and external providers of capital have the same ability to monitor, internal providers will choose to monitor more intensely. This is because they have residual control over the assets, and therefore get more of the gains from monitoring. We are therefore able to put on firmer theoretical footing Alchian's argument in favor of internal capital markets - that they are associated with a better flow of information between users and providers of capital.

2) Decreased entrepreneurial incentives. Giving control rights to capital providers through an internal capital allocation process is costly, however, in that it diminishes managerial incentives. Because the manager does not have control, lie is more vulnerable to opportunistic behavior by corporate headquarters. Thus, the manager may not get all of the rents from his efforts, which reduces his incentives.

3) Better asset redeployability. When corporate headquarters owns multiple related business units, there is an added advantage of an internal capital ınarket. If one unit performs poorly, its assets can be redeployed efficiently: they can be directly combined with the other assets controlled by corporate headquarters. In contrast, an external provider would have to sell the assets to another user and may not get paid their full value.

The starting point for our analysis is a financing model based on Hart and Moore [1989] and Bolton and Scharfstein [1990, 1993]. This model, which is presented in Section l, initially makes no distinction between bank finance and internal finance. This distinction is introduced in Section II, where we also show low the allocation of control rights affects monitoring incentives and entrepreneurship. ${ }^{1}$ Section III focuses on how internal capital allocation improves asset redeployability when the firm owns multiple related business units. 
Section IV concludes the paper.

\section{A Basic Model of Centralized Finance}

The focus of our analysis is an investment project that requires an outlay of $K$ at an initial date 0 , in order to purchase some physical assets. The project also requires the services of a manager who has no wealth of his own. As will become clear, the manager's lack of wealth leads to agency problems in funding the project.

The project has a life of two periods. At date 1 the project produces a random cash flow of either $x$ (with probability $p$ ) or zero (with probability $1-p$ ). This date-1 cash flow is observable to the manager and any potential investor, but is not "verifiable," i.e., it cannot be observed by outside parties and therefore contracts cannot be made contingent on its realization. Moreover, the manager can, if he chooses, costlessly divert all of the cash flow to himself. This formulation captures the notion that there is an agency problem because managers can spend corporate resources on perks, pet projects, etc., and that such spending cannot be directly controlled through contractual means. ${ }^{2}$

The project also las economic value at date 2 , although this date-2 value depends on how the assets are deployed. If the original manager continues to work with the assets, they produce a cash flow of $y$ with certainty at date 2 . We assume that this "continuation" scenario is the most efficient way to use the assets. The only drawback is that continuation enables the manager to divert the non-verifiable cash flow, $y$.

The project can also be "liquidated" after date 1, where liquidation can be thought of as the process of separating the original manager from the assets. Liquidation yields a value of $L$, where $L<y$. The costs of liquidation thus stem from the fact that the assets are not as productive when redeployed without the manager. The benefit of liquidation is that inanagers can no longer divert casbflows to themselves, so investors can obtain the entire value $L$.

This basic formulation follows that of Hart and Moore [1989] and Bolton and Scharfstein $[1990,1993]$. However, we differ from this previous work in our more detailed description of the determinants of asset values, both in the continuation and liquidation scenarios. In our model, both $y$ and $L$ will ultimately be endogenously determined, and will depend on the mode of financing. These variables will be endogenous because, in general, they can de- 
pend on actions taken by both the manager and the investor. The manager's and investor's actions will in turn depend on the incentives associated with a given mode of financing.

As shown in Hart and Moore [1989] and Bolton and Scharfstein [1990, 1993], the optimal contract calls for a repayment of $D$ at date 1 ; if no such payment is made, the investors have the right to seize the project's assets. This contract gives the manager some incentive to make the payment $D$ when he has enough cash to do so because if the manager fails to pay, the assets may be liquidated and be will lose the ability to divert cash to himself at date $2 .^{3}$

A key question in this model is the following: How large a repayment $D$ can actually be extracted from the manager? To answer this question, note first that if the manager pays $D$ when he has cashflow of $x$, the investor has no further leverage over the manager and he will therefore divert all of the date-2 cash flow of $y$ to himself. One can therefore think of $y$ as the "private benefit" that accrues to a manager if he makes the payment $D$. If the manager has cashflow of $x$ and chooses not to make the payment $D$, the investor has the right to liquidate the project. In this case, the investor would receive $L$ and the manager would forfeit $y$. Given that such liquidation is inefficient $(y>L)$ we would expect the manager and the investor to renegotiate to avoid liquidation. Under the assumption of efficient Nash-like bargaining, the two parties would split the resulting surplus, $y-L$. If the manager's share of this surplus is $\beta \epsilon[0,1]$ and the investor's is $1-\beta$, then the manager receives $\beta[y-L]$, the investor receives $\beta L+(1-\beta) y$, and the project is not liquidated. In order for the payment $D$ to be incentive compatible, it must be less than what would be paid out in such a renegotiation. That is, $D$ must be less than $\beta L+(1-\beta) y$. The more bargaining power the manager has, the lower is the threshold level of $D$.

Of course, when the project does not generate any cash at date 1 , there is no scope for renegotiation - the manager does not have the cash to induce the investor not to liquidate. In this case, the manager defaults, and the asset is actually seized by the investors even though its value in this liquidation scenario, $L$, is less than its value under continuation, $y{ }^{*}$

Given these assumptions, we can now calculate the net ex ante return (which we define as $R$ ) to the investor for a given face value of the contract $D$ :

$$
R=p D+(1-p) L-K .
$$


Since the financing contract must satisfy the incentive constraint, $D \leq \beta L+(1-\beta) y$, as well as the investor's participation constraint, $R \geq 0$, the project can be financed only if the following condition is met ${ }^{5}$ :

$$
p[\beta L+(1-\beta) y]+(1-p) L-K \geq 0 .
$$

If (2) is satisfied, competition among investors implies that $D$ will be chosen such that $R=0$. The expected payoff of the manager will be:

$$
p[x+y]+(1-p) L-K
$$

By contrast, if there were no agency problems, the project would be financed as long as it has positive net present value:

$$
p x+y-K \geq 0 .
$$

In this case, (4) is also the expected payoff of the manager.

There are two types of inefficiencies arising from agency problerns. The first is an $e x$ post inefficiency that arises once the project is financed. Since investors always earn zero profits. (4) minus (3) gives the difference in surplus generated by the two regimes. Thus, our ex post measure of inefficiency is:

$$
X P=(1-p)[y-L]
$$

When there are agency problems, the project is inefficiently liquidated in the low cashflow state resulting in a loss of $y-L$ relative to the first best.

The second type of inefficiency is an ex ante inefficiency that arises because positive NPV projects may not get financed in the first place. When there are agency problems the cutoff level of $K$ below whiclı the project will be financed is given by the equality of (2). By contrast the first best cutoff level is given by the equality of (4). Thus, one simple measure of the ex ante inefficiency, $X A$, is the difference in these cutoff levels of $K$. In a model with a continuum of projects with varying levels of $K$, this cutoff level would be related to the probability that the project could be financed. Subtracting (2) from (4) yields our ex ante measure of inefficiency:

$$
X A=p[x+\beta(y-L)]+(1-p)[y-L]
$$


Equation (6) points to two sources of ex ante inefficiency. The most straightforward one is reflected in the second term of (6) which is the same as the ex post inefficiency, $X P$ : because projects are inefficiently liquidated when cash flows are low, investors are less prone to finance the project in the first place. The more subtle inefficiency, reflected in the first bracketed term, stems from incentive compatibility and renegotiation problems. Managers can commit to pay out at most $\beta L+(1-\beta) y$ when cash flows are high even though total value in this case is $x+y$. Thus, investors will be less prone to finance a project when the manager has more bargaining power in renegotiation.

Throughout the rest of the analysis, we will compare the efficiency of internal and external markets using this ex ante measure. We choose this measure because wherever there are ex post inefficiencies they will show up in our ex ante measure of inefficiency. Thus, all of the relevant effects we are interested in show up in $X A$.

\section{Should Centralized Finance be Provided by an Owner or a Lender?}

\section{A. The Distinction Between Lending and Ownership}

The analysis so far is silent on the question of whether the investor should own the project or lend to the manager who owns the project. At first glance, one might think that in this model the manager is the owner and there is no real choice to be made about ownership. This is correct if one accepts the common, informal definition of an owner as the party with residual claims on the firm's cash flows. Under this definition, the manager is the only feasible owner in our model since he receives the residual cashflows.

However, as Grossman and Hart [1986] point out, this is an inadequate definition of ownership. In particular, residual claimants on cashflows do not necessarily have control over how the assets of the firm are used. Such control is clearly a critical aspect of ownership. Thus, we follow Grossman and Hart in defining the owner as that party who "has the residual rights of control of the asset, that is the right to control all aspects of the asset that have not been explicitly given away by contract" (p. 695). In this definition, ownership is most meaningful when there are actions that are ex ante noncontractible - i.e., actions that cannot be prespecified in a contract between two parties. In such cases, an asset's owner is the one who can choose whether or not to undertake tlie noncontractible action. 
The model of Section I does not really address the issue of ownership because the model does not incorporate the sort of noncontractible actions envisioned by Grossman and Hart. ${ }^{\circ}$ On the one land, the model can be interpreted as one in which the manager of the project owns the assets and borrows from a bank. Under this interpretation, $D$ is a required debt payment and the manager has control over the assets as long as he can make the debt payment. If he cannot make the debt payment, he must cede control of the assets to the lender.

On the other hand, one can also interpret the same contract as one where corporate headquarters owns the project and provides financing. Under this interpretation, headquarters signs an incentive contract with the manager that specifies the following: if the manager returns $D$ to headquarters, then lie gets to keep his job; if not, then he is fired. ${ }^{7}$

Given the absence of noncontractible actions it does not matter whether the manager owns the project (and finances with a bank) or whether headquarters owns the project (and allocates capital internally). Our goal in this section is to introduce two noncontractible actions that generate a distinction between these modes of financing: investor monitoring and managerial effort.

\section{B. Ownership and Monitoring}

We begin witl the effect of ownerslip structure on monitoring incentives. Specifically, suppose that at some date between 0 and 1 - call it date $\frac{1}{2}$ - investors can monitor the project. Tlis inonitoring does not directly raise asset values, but instead generates economically valuable "ideas". These ideas must be "implemented" for any value to be realized, and only the asset's owner lias the rigit to decide whether or not to implement any of the ideas generated by the monitoring process.

To take a concrete example, the investor, may in the course of monitoring, notice that the project's assets require some maintenance work. If the investor owns the project, he can ensure that the inaintenance work is carried out; he can hire the needed workers and let them into the plant. In contrast, if the manager owns the project, the investor can only suggest that maintenance would be a good idea; the manager gets to decide whether or not to actually permit such maintenance. To the extent that maintenance primarily raises the liquidation value $L$, it will be in the investor's interest at date $\frac{1}{2}$, hut not in the manager's 
interest. In such cases, it matters who is given ownership of the project. If monitoring and maintenance are valuable, but the manager is not inclined to implement any maintenance work, it may make sense for the investor to own the project.

We assume that the investor can exert some monitoring effort, costing $m$ per unit of effort. The greater is $m$, the better are the ideas generated. These ideas could, in principle, lead to a variety of improvements which could be modeled as increases in expected cash flows (i.e., increases in $p, x$, or $y$ ) or as increases in liquidation values (i.e., increases in $L$ ). As the foregoing discussion suggests, we are most interested in those ideas which entail some conflict over implementation between the investor and the manager. This is why we focus on the effect of monitoring on $L$, and assume that if the ideas generated by monitoring are indeed implemented, $L \equiv L(m)$. More specifically, we choose the functional form $L=\theta(m) L_{0}$, where $\theta(m)$ is an increasing, concave function, with $\theta(0)=1$. If the ideas are not implemented, $L$ is equal to $L_{0}$. In all cases, $L(m)<y$.

How much monitoring will actually take place in equilibrium? We solve the problem by working backwards. Once the monitoring has taken place, there is an expected benefit of (1$p)(\theta(m)-1) L_{0}$ to be realized by implementing the idea. This benefit is simply the probability of default, times the increase in liquidation value that comes from implementation.

All of this benefit accrues to the investor. Therefore, if the investor is an owner, he will certainly implement the idea. This implies that the optimal level of monitoring in an internal capital market, denoted by $m_{l}$, satisfies:

$$
(1-p) \theta^{\prime}\left(m_{l}\right) L_{0}=1 .
$$

Now suppose that the investor is not an owner, but rather a lender. Now once the idea has been generated, only the manager has the right to proceed with implementation. He can therefore hold up the investor for a fraction - call it $\gamma$ - of the surplus generated by implementation. Since the investor can no longer keep all of the benefits from monitoring, his incentive to do so is diminished. Accordingly, the optimal level of monitoring for a bank lender, denoted by $m_{B}$, is given by:

$$
(1-\gamma)(1-p) \theta^{\prime}\left(m_{B}\right) L_{0}=1
$$

Thus, we have established that there is more monitoring when the project is financed 
by an owner (the internal capital market) than by a lender. While an internal market generates the first-best level of monitoring, banks provide too little monitoring. We return to discuss the ex ante efficiency consequences of these results in Section II.D below.

\section{Ownership and Managerial Entrepreneurship}

While an internal capital market may generate more monitoring than bank lending, it may also have some offsetting disadvantages. We now focus on one of these - the effect of ownership on managerial entrepreneurship.

To this point we bave assumed that the continuation value of the project, $y$, is exogenously fixed. Moreover, we have also assumed that if the project is indeed continued, the manager is able to divert all of the continuation value to himself - the investor keeps only $D$, and nothing else.

More realistically, the manager's ability to divert the ongoing proceeds from the project to himself are likely to depend on ownership structure. Consider first the debt interpretation of the contract. As long as the manager has made the payment of $D$ at date 1 , he retains complete control rights through date 2 . Thus, it seems plausible that bis ability to enjoy private benefits will be high.

The ownership interpretation of the contract is a bit subtler. If the project is owned by the investor, the manager does not necessarily have complete control rights through date 2 even if he makes the required payment $D$ at date 1 . Of course, the manager has some contractual protection at date 2 - the contract effectively promises that if the manager returns $D$ to the parent firm, lie gets to keep his job. If such contractual protection for the manager were not feasible, the whole financing scheme would unwind. For note that ex post, once $D$ has been paid to the parent firm, it will always be in the parent's interest to separate the manager from the assets. Sucli ex post opportunism would deprive the manager of any private benefits, and en able the parent to realize $L$ on top of the date-l payment of $D$.

Thus, in order for owner-provided financing to exist at all, it must be that one can write a contract that allows the manager to stay on and enjoy some private benefits at date 2. As noted earlier, this could be accomplished, for example, if one could write a contract of the form: "if you (the manager) turn over $D$ at date 1 , you cannot be fired." However, the subtlety is that promising not to fire someone is not necessarily the same thing as giving them 
complete control (which is what happens with a debt contract). For example, the parentowner might obey the terms of the contract by not firing the manager, but might transfer him to a different office, thereby interfering with his abjlity to enjoy private benefits. If such inter-office transfers were non-contractible, there would be no way of preventing this sort of partial opportunism with owner-provided financing. ${ }^{8}$

The bottom line is that with owner-provided financing, managers' date 2 private benefits may be somewhat protected, but not as well protected as with debt financing. To capture this notion, we make the following assumption: If the project is continued at date 2 and generates an overall value of $y$, the owner is able to capture a fraction $\phi y$, leaving the manager with only $(1-\phi) y .^{9}$

Thus in some sense, owner-provided financing is more "equity-like". Not only does the parent get a fixed payment $D$ at date $l$ (so long as the date-l cashflow is positive), it also captures a share of the continuing value $y$ at date 2 .

This sharing of the continuation value can have ex ante incentive effects, if $y$ is sensitive to managerial effort. To see this, suppose that at some point between date 1 and date 2 - call it date $1 \frac{1}{2}$ - the manager must exert some entrepreneurial effort $e$, and $y \equiv y(e)$ where $y(e)$ is an increasing, concave function. ${ }^{10}$ Knowing that he will have to share $y$ with an owner, the manager will exert less effort than he would were the project debt-financed.

Indeed, when the project is debt-financed, the manager's effort level satisfies $y^{\prime}(e)=$ 1. Denote this effort level by $e_{F}$ (for "first-best"), and let $y\left(e_{F}\right) \equiv y_{F}$. Finally, define $Y_{F} \equiv y_{F}-e_{F}$. Intuitively, $Y_{F}$ is the net-of-effort continuation value when the project is debt-financed.

When the project is owner-financed, the manager's effort level satisfies $(1-\phi) y^{\prime}(e)=1$. Denote this effort level by $e_{S}$ (for "second-best") let $y\left(e_{S}\right) \equiv y_{S}$, and $Y_{S} \equiv y_{S}-e_{S}$. Clearly $Y_{F}>Y_{S}$, since $Y_{F}$ is the maximal value of $y-e$.

\section{The Ex Ante Efficiency of Internal and External Markets}

We now calculate the ex ante efficiency of internal and external markets and compare them. In an external market, the ex ante measure of inefficiency is:

$$
X A_{B a n k}=p\left[x+\beta\left(Y_{F}-L_{B}\right)\right\}+(1-p)\left(Y_{F}-L_{B}\right)+m_{B}+(1-p) \gamma\left(L_{B}-L_{0}\right),
$$


where $L_{B} \equiv L\left(m_{B}\right)$ is the liquidation value given bank monitoring of $m_{B}$.

The first two terms of (9) are identical to the ex ante measure (6) except that in (9) $y$ and $L$ are endogenous. The third term is the direct monitoring cost. Finally, the fourth term is the surplus that the bank has to share with the manager in order to implement the ideas generated by monitoring.

In an internal market, the ex ante measure of inefficiency is:

$$
X A_{\text {Internal }}=p\left[x+\left(Y_{F}-Y_{S}\right)+\beta\left(Y_{S}-L_{I}\right)\right]+(1-p)\left(Y_{F}-L_{I}\right)+m_{I}
$$

We are now in a position to compare the two modes of financing directly. Define $\triangle X A=X A_{\text {Bank }}-X A_{\text {Internal }}$. The larger is $\triangle X A$, the more attractive is internal capital allocation relative to bank financing. Using equations (9) and (10), we can write:

$$
\begin{aligned}
\Delta X A= & -p\left(Y_{F}-Y_{S}\right)+\left\{(1-p)\left(L_{I}-L_{B}\right)-\left(m_{I}-m_{B}\right)\right\}+(1-p) \gamma\left(L_{B}-L_{0}\right)+ \\
& p \beta\left\{\left(Y_{F}-L_{B}\right)-\left(Y_{S}-L_{I}\right)\right\} .
\end{aligned}
$$

The first term, $-p\left(Y_{F}-Y_{S}\right)$, indicates that an external market is more favorable to the extent that it leads to higher continuation values net of effort costs. The second term, $\left\{(1-p)\left(L_{l}-L_{B}\right)-\left(m_{I}-m_{B}\right)\right\}$, indicates that an internal market is more favorable to the extent that it leads to higher liquidation values net of monitoring costs. The sum of these two terms is also the difference in the ex post efficiency of internal and external markets. The third and fourth terms relate to the surplus that is extracted by the manager in ongoing bargaining over the life of the contract. Botli of these terms tend to make internal financing more attractive than external financing. The third term, $(1-p) \gamma\left(L_{B}-L_{0}\right)$, captures the idea that in an external market the manager can extract more of the surplus generated by investor monitoring at date $\frac{1}{2}$. The last term captures the idea that in an external market the manager can extract more rent from the investor by threatening to default at date 1 . This is because the manager's private benefit from continuation is higher and the liquidation value lower in an external market, i.e. $Y_{F}-L_{B}>Y_{S}-L_{J}$. Loosely speaking, both the third and fourth terms suggest that an internal market has the advantage of improving the investor's bargaining position over the life of the contract, thereby allowing him to recover more of his investment. 


\section{Asset Redeployability and the Financing of Related Projects}

\section{A. The Basic Idea}

Thus far, we have focused on the financing of a single project in isolation. While this highlights some of the key distinctions between an internal and external market, it ignores potential interactions across different projects. We show in this section that internal capital markets have an added advantage over bank financing when headquarters finances multiple related projects.

The basis of our argument is that it is easier for corporate beadquarters to redeploy assets within the firm than for a bank lender to sell assets externally. To see why this is important, suppose that there are two biotechnology projects, $A$ and $B$. Both have their own managers and their own specialized assets. Now suppose that project A performs poorly, and in the language of our model, is in default at date 1. At the same time, project $B$ performs well, and does not default.

The bank will clearly wish to separate the assets from the manager of project $A$. But how are these project- $A$ assets to be redeployed? The bank would probably not want to manage them itself, given that it has no managerial expertise in biotechnology. A better alternative would be to redeploy the assets to the next highest value user. In this case, suppose it is project $B$ with its related assets and managerial expertise.

However, since the bank does not own project $B$, the bank cannot directly compel project B's management to take on the project- $A$ assets. The best the bank can do is to sell the assets to $B$ at a price somewhere between their value to $B$ and their value to the bank - that is, the bank will lave to share the surplus with the manager of project $B$.

Things would work differently if projects $A$ and $B$ were both financed by a single owner rather than by a lender. Now if the assets from project $A$ need to be redeployed, and the best way to do so is by combining them with the assets of project $B$, an owner can directly effectuate such a combination. An owner does not need to resort to an asset sale, and thus does not have to share any of the surplus with another party.

The difference between ownership and lending in this example again flows from the logic of Grossman and Hart [1986], as developed further by Hart and Moore [1990]: "...the sole right possessed by the owner of the asset is his ability to exclude others from the use 
of the asset". (page 1121). Thus when project B's assets are owned by their manager (the case of bank lending) this manager does not liave to accept a combination of the assets of $A$ and $B$, and must be bribed. In contrast, when project $B$ 's assets are owned by the party who is also financing project $A$, the manager of project $B$ cannot prevent the assets of the two projects from being combined. The result is that "internal liquidations" generate more value for headquarters than "external liquidations" (assets sales) do for banks.

To develop these ideas formally, we must bave a model in which liquidation values depend on who owns the assets. Until now, we have implicitly assumed that any party who obtains these assets can redeploy them and obtain the second-hest liquidation value, $L$. This assumption may be reasonable if the project's assets are primarily non-specific ones such as land and buildings. However, in other situations, the assumption will be highly implausible. For example, if the project is biotechnology R\&D, a bank is probably a lower value user of the assets than other biotechnology firms.

To capture this notion in our model, we continue to assume that the first-best use of the assets generates a continuation value of $y(e)$ in the hands of the original manager. In addition, efficient redeployment of the assets generates a value of $L(m)$. However, this value can only be realized if the project's assets are combined with specific "related assets".

The new aspect of the model is that if the project is not efficiently redeployed, say because it is not combined with the related assets, it generates a value of only $(1-s) L(m)$, where $0<s<1$. One can think of $s$ as an index of the "specificity" of the assets - if $s=0$, the assets are completely non-specific and we are back to our earlier formulation. If $s=1$, the assets are completely specific, in the sense that they are worthless unless combined with the related assets. ${ }^{11}$ In our previous examples, $s$ would be large for the biotechnology assets and small for the land and buildings.

\section{B. Internal Capital Allocation with Related Projects}

Suppose that headquarters finances two related projects, $A$ and $B$, in an internal capital market. We will focus on developing an $X A$ measure for project $A$ which is assumed to be identical to the project we have been analyzing. For simplicity, suppose that project $B$ is never in default. As will become clear, this assumption does not entail a meaningful loss of generality - all that is really needed for our hasic point is that the date-l outcomes of the 
two projects are not perfectly correlated.

The analysis for project $A$ in this case is exactly identical to that in Section II.C ahove. In a liquidation scenario, the parent can, by virtue of its ownership rights, combine the project-A assets with the project-B assets, and therehy generate a liquidation value of $L(m)$. Thus, our $X A$ measure in this case is still given by equation (10).

One question that arises in this case is this: Won't the manager of project $B$ try to extract some of the surplus from efficient redeployment, $s(m)$ ? The answer is that he has no credible way to do so. If the manager of project $B$ has an incentive contract of the form described earlier, and he has not defaulted, his options are as follows: 1) He can continue working with the combined $A$ and $B$ assets. In this case, be derives a date-2 private benefit of $(1-\phi) y_{0}^{B}-e_{0}^{B}$. That is, he gets to enjoy the same net private benefits that he would were he only managing the project-B assets. 2) Alternatively, the manager of project $B$ can quit - that is, refuse to work with the combined assets. However, if he does so, he loses the private benefits that come with managing the assets of project $B$. Thus, the threat to quit is not credible, and the manager of project $B$ has no way of holding up headquarters for some of the redeployment value. ${ }^{12}$

What is crucial to this logic is that, since the manager of project B does not own B's assets, he does not have the option to prevent the combination of the A- and B-assets. In other words, he cannot choose to continue working with only the B-assets. If he did have this choice - and this will be the case when there is bank financing - he would be in a position to hold up the party seeking to redeploy the A-assets.

\section{Bank Financing with Related Projects}

Now suppose a single bank finances both projects. Here, the key point is that the bank cannot ohtain the full $L(m)$ when it has to liquidate project $A$. The bank, seeking to maximize its liquidation proceeds, approaches the manager of project $B$ and suggests that they combine the $\mathrm{A}$-assets and the $\mathrm{B}$-assets. Relative to any other alternative redeployment strategy, this combination generates a surplus of $s L(m)$. However, since the manager of project $B$ now also owns the B-assets, he can refuse to accept the proposed combination.

The result is that the bank will iave to share a fraction of the surplus with the manager of project $\mathrm{B}$. If we denote the bank's share of the surplus by $\alpha<1$, the hank's net proceeds 
from the asset sale are $(1-s+\alpha s) L(m)<L(m)$.

We can now rework the $X A$ measure in equation (9) accordingly. In particular, we now have

$$
\begin{aligned}
X A_{B a n k}= & p\left[x+\beta\left(Y_{F}-(1-s+\alpha s) L_{B}\right)\right]+(1-p)\left[Y_{F}-(1-s+\alpha s) L_{B}\right] \\
& +(1-s+\alpha s)(1-p) \gamma\left(L_{B}-L_{0}\right)+m_{B}
\end{aligned}
$$

where $L_{B} \equiv L\left(m_{B}\right)$ and $m_{B}$ now satisfies the new first order condition:

$$
(1-\gamma)(1-s+\alpha s)(1-p) \theta^{\prime}\left(m_{B}\right) L_{0}=1
$$

Now, the bank has an additional reason to monitor less than headquarters - ex post the bank realizes only a fraction of any improvements to liquidation value because it has to share the surplus $s L(m)$ with the project-B manager.

We can also calculate an analog to equation (11), and revisit the comparison between internal capital allocation and bank financing:

$$
\begin{aligned}
& \Delta X A=-p\left(Y_{F}-Y_{S}\right)+\left\{(1-p)\left[L_{I}-(1-s+\alpha s) L_{B}\right]-\left(m_{I}-m_{B}\right)\right\}+ \\
& (1-p) \gamma(1-s+\alpha s)\left(L_{B}-L_{0}\right)+p \beta\left\{\left(Y_{F}-(1-s+\alpha s) L_{B}\right)-\left(Y_{S}-L_{l}\right)\right\} .
\end{aligned}
$$

This expression for $\triangle X A$ includes all the same basic effects as those in the singleproject model of Section II. In fact, when $s=0$ the two expressions are identical. However, when $s>0,(14)$ is greater than (11); internal capital markets have an added advantage over external markets when the firm owns related assets. In external markets, net liquidation values are effectively lowered by a factor of $(1-s+\alpha s)$.

\section{Discussion}

The critical assumption that underlies this analysis is that in an asset sale, the seller does not get paid the full first-best redeployment value of the asset. There are two reasons why this may be the case. First, if buyers have heterogeneous valuations of the asset, the high bidder only needs to pay the second highest value. Second, as Shleifer and Vishny [1992] point out, credit constraints can prevent bidders from paying their full reservation values. Indeed, Asquith, Gertner auu Scharfstein [1994] provide indirect empirical support 
for these ideas. They find that financially distressed firms are less likely to sell assets when others in their industry are distressed or have high leverage. A natural interpretation is that when high-value industry buyers are credit constrained (because of an industry downturn or high leverage), asset sales generate lower transaction prices and therefore are less attractive.

The main empirical implication that emerges from this analysis is that business-unit managers inside related conglomerates will be more likely to be replaced in an internal shakeup following poor performance than either (1) top managers of comparable stand-alone firms; or (2) business-unit managers inside unrelated conglomerates. The flip side of this prediction is that the assets of business units in related conglomerates will be less likely to be sold off to outside buyers than the assets of comparable stand-alone companies or the assets of business units in unrelated conglomerates.

Gupta and Govindarajan [1986] that present survey evidence that is loosely consistent with the implications of our model. In their study of 58 business units in eight large corporations, they find a weak negative correlation between managerial tenure at the business unit level and the degree to which the business unit is related to others in the company. This finding suggests that there is higher managerial turnover in the business units of related conglomerates than in the business units of unrelated conglomerates. In addition, in their survey, the managers of related business units report lower job satisfaction than those of unrelated business units. This finding is consistent with the spirit of our model - in related conglomerates business-unit managers have less bargaining power and are less able to extract rents. Of course, there are competing explanations of these results, but they suggest an avenue for further empirical research.

With regard to asset sales, Kaplan and Weisbach [1992] present evidence that conglomerates are four times more likely to sell off their unrelated acquisitions than their related acquisitions. Although this fact too could have many explanations, it is consistent with the implication of our model that firms can simply replace managers of poorly-performing related lines of business, rather than selling the assets of those units.

\section{Conclusions}

In many ways, our treatment $;-$ internal capital allocation has been a quite narrow one. We have built the entire analysis on a single key observation - that, unlike external 
bank lending, internal capital allocation gives corporate headquarters the residual rights of control over the assets in question.

The good news is that even this very minimalist modeling approach yields some fairly detailed implications about the strengths and weaknesses of internal vs. external capital markets. In particular, we have seen that the ownership aspect of internal capital allocation has three significant consequences: it leads to more monitoring and hetter asset redeployability than bank lending, but this comes at the cost of reducing managers' entrepreneurial incentives.

The bad news is that while we think it represents a useful start, our narrow approach surely leaves many important things out. Perhaps most notably, we have ignored the potential for information or agency problems at the level of the provider of capital. In our model, the bank lenders and corporate headquarters that fund agency-prone projects are themselves both profit-maximizers and free of any sort of credit constraints.

These assumptions prevent us from addressing a number of potentially interesting questions. For example, if there are agency prohlems at the level of the capital provider, one might ask whether these problems are somehow exacerbated in an internal market - i.e., is headquarters more inclined to make inefficient investments than a bank lender? One reason this might be the case flows from the monitoring results we established above. Suppose that monitoring involves actual on-site visits by the investor's agents, where they interact with the business-unit managers. The more monitoring, the more such interaction, and the more scope there is for business-unit managers to engage in influence activities. In other words, our results on endogenous monitoring tell us that headquarters staff will be in closer contact with business-unit managers than would be bank loan officers; hence they are more likely to be wined and dined and ultimately won over by them. This may make it harder for headquarters staff to perform a useful disciplinary role.

With regard to credit constraints, one might ask the following: if one business unit of a conglomerate has a very bad year, causing the conglomerate as a whole to be pinched for cash, how is the investment behavior of its other units affected? Do liquidity prohlems somehow spill over from one business unit to another ${ }^{23}$ This would seem to be a promising direction for future research.

UNIVERSITY OF CHICAGO

MASSACHUSETTS DSTITUTE OF TECHNOLOGY and NATIONAL BUREAU OF ECONOMIC RESEARCH MASSACHUSETTS DSTITUTE OF TECHNOLOGY and NATIONAL BUREAU OF ECONOMIC RESEARCH 


\section{References}

Alchian, Armen, "Corporate Management and Property Rights," Economic Policy and the Regulation of Corporate Securities, Henry Manne, ed., Washington, DC, American Enterprise Institute, (1969), 337-360.

Aghion, Phillipe and Jean Tirole, "Formal and Real Authority in Organizations," Working Paper, 1994.

Asquith, Paul, Robert Gertner and David Scharfstein, "Anatomy of Financial Distress: An Examination of Junk-Bond lssuers," Quarterly Journal of Economics, CIX (1994), forthcoming.

Bolton, Patrick and David Scharfstein, "A Theory of Predation Based on Agency Problems in Financial Contracting," American Economic Review, LXXX (1990), 93-106.

Bolton, Patrick and David Scharfstein, "Optimal Debt Structure with Multiple Creditors," Massachusetts Institute of Technology Working Paper, 1993.

Diamond, Douglas, "Financial Intermediation and Delegated Monitoring," Review of Economic Studies, LI (1984), 393-414.

Directory of Corporate Affiliations, Reed Reference Publishing, New Providence, NJ 1994.

Grossman, Sanford and Oliver Hart, "The Costs and Benefits of Ownership: A Theory of Vertical and Lateral Integration," Journal of Political Economy, XCIV (1986), 691-719.

Gupta, Anil and Vijay Govindarajan, "Resource Sharing Among SBUs: Strategic Antecedents and Administrative Implications," Academy of Management Journal, XXIX (1986), 695-i14.

Hart, Oliver and Jolnn Moore, "Default and Renegotiation: A Dynamic Model of Debt," Massachusetts Institute of Technology, Working Paper, 1989.

Hart, Oliver and Jolın Moore, "Property Rights and the Nature of the Firm," Journal of Political Economy, XCVIII (1990), 1119-1158.

Lamont, Owen, "Cash Flow and Investment: Evidence from Internal Capital Markets" Massachusetts Institute of Technology, Working Paper, 1993.

Shleifer, Andrei and Robert Vishny, "Liquidation Values and Debt Capacity: A Market Equilibrium A pproach," Journal of Finance, XLVII (1992), 1343-1366.

Williamson, Oliver, Markets and Hierarchies: Analysis and Antitrust Implications: A Study in the Economics of Internal Organization, (New York, NY), 1975. 


\section{Endnotes}

1. A similar point in a different conter.t is made by Aghion and Tirole [1994].

2. This formulation is an extreme way to model such agency problems in that managers benefit fully from every dollar that they divert from investors.

3. Note that we are assuming that default is verifiable and that one can write contracts specifying when the asset is to be transferred from one party to another.

4. In the text we restrict attention to standard debt contracts in which the manager raises $K$ in funding and promises to return some amount $D$. However, Oliver Hart has pointed out an example of a non-standard contract that avoids ex post inefficient liquidation. Suppose $D=\infty$ and the investor provides a date- 0 transfer to the manager of $t$ in excess of $K$. Suppose also that the investor has all the bargaining power in renegotiation. In this case, the manager always defaults. The manager's value from continuing is $y$. When cashflows are high the manager can afford to pay $y$ to avoid liquidation, whereas when cashflows are low the managet can only afford to pay $t$. Provided $t \geq L$, the investor will choose not to liquidate. One can show that as long as $p(y-L) \geq K$, this contract is feasible and liquidation never occurs. The manager's expected payoff given zero profits for the investor is the first-best level, $p x+y-K$.

Although this contract achieves the first-best if it is feasible, there are three reasons to focus on the standard debt contract. First, the non-standard debt contract is less likely to be feasible than the standard debt contract we have been analyzing. The condition for the standard debt contract to be feasible is $p(y-L)+L \geq K$, which is a less stringent condition.

Second, the non-standard debt contract does not achieve the first-best solution when the asset can be partially liquidated. In this case, the investor would demand a payment of $t$ in the low cash flow state in exchange for not liquidating fraction $\frac{1}{y}$ of the asset. The remaining part of the asset would be liquidated. In fact, one can show that transfers of this sort are equivalent to a standard debt contract without up-front transfers, but where the investor commits to liquidating no more than some amount $z$ of the asset following a default.

Finally, the proposed contract is vulnerable to an extreme form of opportunism. Suppose that investors cannot determine ex ante whether managers have real projects in which to invest. In particular, there are "bogus" managers who can spend $K$ on somelhing that looks like a project, but in fact generates no cashflows. In the non-standard debt contract, 
they will be given $K+t$, spend $K$ ind walk away with the remaining $t$. If this contract attracts enough of these bogus managers, it will not be feasible. By contrast, the standard debt contract does not encourage this sort of opportunism. Bogus managers would spend $K$, but have no subsequent cashflows and therefore earn no rents. This is one reason why we may not observe debt contracts which provide funding in excess of the required investment. Therefore, we restrict attention to standard debt contracts because they are optimal in reasonable settings and they generate a realistic set of inefficiencies.

5. We assume a zero required return for simplicity.

6. The one variable that is noncontractible in the model of Section $I$ is whether or not the project's manager diverts funds to himself. However, the ability to divert cash flows is intrinsic to the manager and is not a right that can be transferred hy assigning ownership to another party.

7. This ownership interpretation of the contract makes the strong assumption that an owner can contractually commit not to interfering whatsoever with the manager's consumption of private benefits at date-2. That is, promising not to "fire" the manager if he delivers $D$ is contractually equivalent to promising that the manager can keep all of the continuation value of $y$ if he delivers $D$. We examine this assumption in detail in II.C below.

8. An example of a contract that offers protection from firing, hut at the same time does not offer complete control is an academic tenure contract. Professors with tenure certainly are able to enjoy some rents, but the party with the residual rights of control (i.e. the Dean) can reduce these rents by assigning teaching loads, offices, etc.

9. We need to assume $\phi y<L-$ otherwise, it will not be in owner's interest to liquidate when the manager defaults at date 1 .

10. One tricky issue raised by locating managerial effort at date $1 \frac{1}{2}$ is that it might make sense for the investor to own the project through date 1 (to encourage monitoring) and then to transfer ownership to the manager if he makes the payment $D$ (to encourage entrepreneurial effort). We do not allow for such transfers of ownership in the model. If the manager were to choose effort at date $\frac{1}{2}$ this conditional transfer of ownership would not be an issue. However, the model would be more complicated because if effort is chosen before $D$ is paid, managers have an additional strategic reason not to exert effort - this lowers the 
value of $y$ which is useful in a renegotiation over the size of the date-1 payment $D$. Since we do not find this effect to be particuli:rly interesting, we choose instead to locate managerial effort at date $1 \frac{1}{2}$.

11. Also as in the earlier version of the model, we need to assume that investors bave no trouble getting their hands on the redeployment values - i.e., these cashflows cannot be diverted by managers.

12. For simplicity, we have assumed that when the A- and B-assets are combined, the manager of project $B$ is not able to divert any more in the way of private benefits than when he just oversees the B-assets. In other words, all the incremental value $L(m)$ that comes from combining the assets can be appropriated by the investor. However, this is not crucial we could extend the analysis to consider the case where the B-manager's private benefits increase somewhat when the assets are combined. It would still generally be the case that the B-manager extracts less surplus under internal capital allocation than under bank lending, which is all that matters for our results.

13. Recent empirical work by Lamont [1993] suggests that such intra-firm liquidity spillovers do indeed take place. He found that when oil companies' profits were hurt by the drop in oil prices in 1986, they cut investment not only in their oil-related divisions, but also in their non-oil-related divisions. 